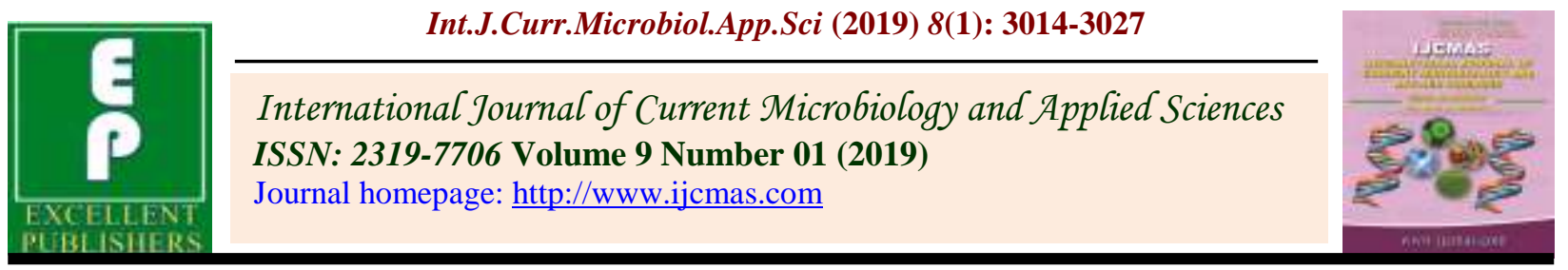

Case Study

https://doi.org/10.20546/ijcmas.2019.801.321

\title{
Halfa and Cogon: The Two Novel Grasses
}

\author{
Priti Madhukar Gaikwad, Shubhangi Shankar Pawar \\ and Vitthalrao Bhimasha Khyade*
}

Science Association, Shardabai Pawar Mahila Mahavidyalaya, Shardanagar, Tal. Baramati, Dist. Pune-413115, India

*Corresponding author

\begin{tabular}{l} 
Ke y w or d s \\
Halfa grass, \\
$\begin{array}{l}\text { Desmostachya } \\
\text { bipinnata }(\mathrm{L}), \\
\text { Cogon grass, } \\
\text { Imperata cylindrica } \\
\text { (L) }\end{array}$ \\
\hline Article Info \\
$\begin{array}{l}\text { Accepted: } \\
\text { 26 December } 2018 \\
\text { Available Online: } \\
\text { 10 January } 2019\end{array}$ \\
\hline
\end{tabular}

The most successful plants on earth are the grasses. They are monocotyledonous plants. They have been a survivor on the planet despite of various ecological changes. They deserve the medicinal value and therefore considered as novel repositories. The grass family is considered as sacred. It has great significance in ayurveda because of medicinal as well as clinical properties. The Desmostachya bipinnata (L.) (commonly recognized as halfa grass, big cordgrass, and salt reed-grass) and Imperata cylindrica (L.) (commonly recognized as cogon grass, kunai grass, blady grass, alang-alang, lalang grass, cotton wool grass, kura-kura) are the two grasses that constitute vital ingredient in various Vedic sacrifices (Yagnas) and rituals. These two grasses are found along river beds and plains throughout India. Both of them are well known for their medicinal properties as supported by traditional Ayurvedic scriptures. They are the vital component in traditional medicinal formulations such as Tripan chamool, Kusadya-ghrita and Kusablecha, that are used to treat many disorders such as dysentery, diuresis, jaundice, skin infections like disease. The present attempt is the review enlightening the bioactive molecules such as flavonoids, glycosides isolated from these two grasses. The ecological monitoring is one of the essential strategies required for the conservation of biodiversity of the medicinal plants.

\section{Introduction}

Secondary metabolism in plants produces a large number of specialized compounds (estimated 200,000) that do not aid in the growth and development of plants but are required for the plant to survive in its environment. Secondary metabolism is connected to primary metabolism by using building blocks and biosynthetic enzymes derived from primary metabolism. Primary metabolism governs all basic physiological processes that allow a plant to grow and set seeds, by translating the genetic code into proteins, carbohydrates, and amino acids. Specialized compounds from secondary metabolism are essential for communicating with other organisms in mutualistic (e.g. attraction of beneficial organisms such as pollinators) or antagonistic interactions (e.g. deterrent against herbivores and pathogens). They further assist in coping with abiotic stress such as increased UV-radiation. The broad functional spectrum of specialized 
metabolism is still not fully understood. In any case, a good balance between products of primary and secondary metabolism is best for a plant's optimal growth and development as well as for its effective coping with often changing environmental conditions. Well known specialized compounds include alkaloids, polyphenols including flavonoids, and terpenoids. Humans use quite a lot of these compounds, or the plants from which they originate, for medicinal and nutraceutical purposes. The chemicals derived from any living organism - plants, animals or microbes are designated to be the natural products (Samuelsson, 1999). The natural products could be primary metabolites or the secondary metabolites. The primary metabolites are required for the growth of organism. The secondary metabolites are predominantly required for defense and sustenance of the organism (Bhat, 2005). The herbs or medicinal plants are concerned with production of secondary metabolites. The recognition of herbs and their utilization for management of diseases could be dated back to antiquity. The herbal products are applied alone. They may also apply as a formulation in combination of crude or bioactive principles for therapy. The authentic literature on the applications of the herbal formulations is available in various scripts and texts. These sources of information are now preserved and entitled as sacred. Till today, the sacred literatures are referred for rediscovery and isolation of pure bioactive molecules for therapy. The present attempt is trying it's best to narrate the comprehensive background about the ethnic and modern day significance of two medicanal plants: Halfa grass, Desmostachya bipinnata (L); Cogon grass, Imperata cylindrica (L) appearing in sacred texts. Both of them are regarded as sacred because of their medicinal value, and use in ritualistic practices.

The halfa grass, Desmostachya bipinnata (L.) Stapf. (Fam. Poaceae) is also called as Big cord grass. It is culturally important grass. In India, halfa grass, Desmostachya bipinnata (L.) is called as Kusha in Sanskrit language. Halfa grass is with three species under its genus, D. bipinnata, D. cynosuroides Stapf ex Massey, D. pingalaiae Raole \& R. J. Desai. One more important Vedic grass is cogon grass, Imperata cylindrical (L.) P. Beauv. (Fam. Poaceae). In Sanskrit language, it is recognized as Dharbha. It has nine species under its genus. According to Gabel (1982), the nine species of cogon grass include: $I$. conferta; I. cylindrica; I. contracta; I. brevifolia; I. brasiliensis; I. tenius; I. cheesemanii; I. condensate; and I. minutiflora. The halfa grass and cogon grass both are widely used in various religious sacrifices and rituals in India. It has been mentioned in Rigveda and Atharvaveda (Madhihassan, 1987). Both of them are perennial green grasses with dense foliage and are always seen spread over vast areas. There is major problem with large scale production of any natural products. For example, the availability of source, which usually gets exhausted.

The major significance of the described grasses is that they are abundantly available and are therefore sustainable sources. Even though, both the mentioned plants have various biologically active principles and medicinal value, they have been utilized barely for commercial therapeutic solutions. Thus, this review aims to provide a major leap towards awareness, understanding and utilization of medicinal principles from these plants. Emphasis is given on natural products isolated so far and activity of these bioactive compounds and extracts of these plants.

Let us have a review on literature pertaining the halfa grass, Desmostachya bipinnata (L.) and cogon grass, Imperata cylindrical (L.). Towards review, the present attempt is trying it's best to explain both the grass plants with reference to: Ethnic prominence; Bioactive 
compounds isolated and Bioactivity of extracts

The halfa grass, Desmostachya bipinnata (L.)

Desmostachya bipinnata (L.) grows commonly and abundantly in fallow agricultural fields, along roadsides and on boundaries and bunds of agricultural fields on dry and sandy soils. It often forms dense tufts producing a dominating patch of plants. Desmostachya bipinnata (L.) is one of the hardiest and most aggressive weeds in agricultural fields. It is growing either with the crop or on field margins. It is very difficult to manage or eradicate established populations of Desmostachya bipinnata (L.). Desmostachya bipinnata is native to northeast and west tropical, and northern Africa (in Algeria, Chad, Egypt, Eritrea, Ethiopia, Libya, Mauritania, Somalia, Sudan, and Tunisia); and countries in the Middle East, and temperate and tropical Asia (in Afghanistan, China, India, Iran, Iraq, Israel, Myanmar, Nepal, Pakistan, Saudi Arabia, Thailand) (Fig. 1).

\section{Ethnic prominence of Desmostachya bipinnata (L.)}

The halfa grass, Desmostachya bipinnata (L), the significant member of family Poaceae is commonly known as sacrificial grass. The reason for it's sacrificial recognition is it's use in Yagnas and religious rites (Sivaranjan and Indira, 1994). It is a tufted perennial grass with thick scaly root stocks, which sends out creeping rhizomes in all directions. Leaves of the grass are many; reach up to $50 \mathrm{~cm}$ long and $1 \mathrm{~cm}$ broad at the base (Prajapati et al., 2003). The halfa grass, Desmostachya bipinnata (L) is distributed throughout India in hot and dry places and also found in Nubia, Egypt and Syria (Kirtikar and Basu, 1918). Roots of this grass are used in the Indian traditional system of medicine as cooling, sweet, astringent, diuretic and galactagogue. They are also useful in dysentery, diarrhoea, urinary calculi, dysuria, other diseases of bladder and skin diseases (Joshi, 2003). The culms (the jointed stem of grasses, usually hollow) are said to possess diuretic and stimulant properties. In the Konkan region, they are prescribed in compound decoctions with more active drugs for the cure of dysentery, menorrhagia, etc. (Kirtikar and Basu, 1918). Almost all the Vedic rituals have Kusha (the halfa grass, Desmostachya bipinnata L) as one of their ingredient. The mat or asana (In yoga, an asana posture in which a practitioner sits) to perform vedic rituals is made out of this sacred plant. Ring made through the use of this grass is worn in ring finger during the ritual (Bhalla, 2006). Desmostachya bipinnata (L) has long been used in various traditions as a sacred plant. According to early Buddhist accounts, this grass was the material used by Buddha for his meditation seat when he attained enlightenment. This grass was mentioned in the Rig Veda for use in sacred ceremonies and also as a seat for priests and the gods. Kusha grass, Desmostachya bipinnata (L) is specifically recommended by Lord Krishna in the Bhagavad Gita as part of the ideal seat for meditation. In arid regions, Kusha grass, Desmostachya bipinnata (L) has been used as fodder for livestock. In agriculture, this grass is a weed commonly found in wheat crops (Ahmad and Shaikh, 2003).

\section{Bioactive compounds isolated from Desmostachya bipinnata (L.)}

The crude phytochemical screening of Kusha grass, Desmostachya bipinnata (L) reveal various classes of molecules such as alkaloids, flavonoids, terpenoids, glycosides, saponins, contents (Hegde et al., 2010). Out of which, only few compounds have been isolated and characterized from Kusha grass, Desmostachya bipinnata (L). Singh et al., 
(2014) reported phytochemicals such as alkaloids, tannins, flavonoids, steroids, glycosides, and coumarins in Kusha grass, Desmostachya bipinnata (L). Hifnawy et al., (1999) and Packialakshmi et al., (2014) confirmed and reported through High Performance Liquid chromatography (HPLC) the presence of coumarins, scopoletin and umbelliferone phytochemicals Later, flavonoids like kaempferol, quercetin, glucoside and trycin compounds were also confirmed. These compounds were already reported from other herbal sources and they are well known for their bioactivity. However, the trycin was reported to be anti-ulcerogenic. The trycin had curative ratio of about 79.49 to 80.4 percent for ethanol induced ulcer in male Wistar rats (Amani et al., 2008). Ramadan et $a l$. ., (2009) isolated 4'-methoxy quercetin-7-Oglucoside was isolated from Kusha grass, Desmostachya bipinnata (L). This 4'-methoxy quercetin-7-O-glucoside was found working effectively against Helicobacter pylori with MIC of $62 \mu \mathrm{g} / \mathrm{ml}$ (Ramadan et al., 2009). Further studies in Kusha grass, Desmostachya bipinnata (L) yielded sterol molecules, which include: stigmasterol, $\beta$-sitosterol, daucosterol, stigmast-5-en-3 $\beta$, 7 $\beta$-diol, and stigmast-5-en$3 \beta, \quad 7 \beta$-diol (Shrestha et al., 2011). Daucosterol or $\beta$-sitosterol- DGlucopyranoside was also reported to act synergistically against common human pathogensalong with other commercial antibiotics especially ciprofloxacin. Time kill analysis showed that it killed most of the pathogens in 5-10 h (Subramaniam et al., 2014).

A new compound "xanthene 2,6-dihydroxy-7methoxy-3H-xanthen-3-one" was recently isolated from Kusha grass, Desmostachya bipinnata (L). This compound "xanthene 2,6dihydroxy-7-methoxy- 3H-xanthen-3-one" exhibited inhibitions of signal transducer and activator of transcription 3-dependent luciferase activity in HCT-116 colon cancer cell line with IC50 value of $5 \mu \mathrm{M}$ and lowdensity lipoproteinoxidation with IC50 value of 27.2 $\mu \mathrm{M}$ (Shrestha et al., 2011). 5Hydroxymethyl 2-furfural, along with $\beta$ amyrin, $\beta$-sitosterol, $\beta$-stisterol glucoside, stigmasterol glucoside and sucrose were isolated and reported first time from the ethanolic extract of the rootstock of Kusha grass, Desmostachya bipinnata (L) (Shakila, et al., 2015).

\section{Bioactivity of extractives from Desmostachya bipinnata (L)}

The roots of Kusha grass, Desmostachya bipinnata (L) are cooling, diuretic, galactagogue, emollient, aphrodisiac, astringent, used for menorrhagia, diarrhea, dysentery, skin disease, renal and vesical calculi, asthma, jaundice, dysurea, bleeding piles, burning sensation, cystitis, dispesis, vaginal discharges and erysipelas (The Ayurvedic Pharmacopoeia of India, Government of India Ministry of Health and Family Welfare Department of Ayush). Various bioactivities substantiate the medicinal properties of Kusha grass, Desmostachya bipinnata (L). Studies on acute toxicity of alcoholic and aqueous root extracts of this Kusha grass, Desmostachya bipinnata (L) showed it to be safe till $2000 \mathrm{mg} / \mathrm{Kg}$ body weight in female albino mice. Studies on aqueous and alcoholic extracts of roots, revealed the anti-diarrheal activity with alcoholic extract showing $29.34 \%$ and $34.36 \%$ inhibition of diarrheal symptoms at 200 and $400 \mathrm{mg} / \mathrm{Kg}$ body weight of Albino mice. The aqueous extract of Kusha grass, Desmostachya bipinnata (L) showed only 24.68 and $27.57 \%$ inhibition at 200 and $400 \mathrm{mg} / \mathrm{Kg}$ respectively (Hegde et al., 2010). This attempt was confirming ethnic use of Kusha grass, Desmostachya bipinnata (L) in treating diarrheal indications. The hydro-methanolic extract of whole plant of Kusha grass, Desmostachya bipinnata (L) was administered 
to normal Wistar albino rats for the purpose to study the changes in euglycemic index. This attempt revealed that, in hypoglycemic state (induced by exercise or work) and hyperglycemic state (induced by food consumption etc.), the extracts of Kusha grass, Desmostachya bipinnata (L) maintained the euglycemic index. Thus, use of Kusha grass, Desmostachya bipinnata (L) in traditional medicine for diabetic patients along with other herbs was evident (Golla et al., 2013). Further studies with hydro-methanolic extract of whole kusha grass, Desmostachya bipinnata (L) elucidated its use in airway and gut disorders.

This hydro-methanolic extract of whole kusha grass, Desmostachya bipinnata (L) (100-500 $\mathrm{mg} / \mathrm{Kg}$ ) not only protected mice against castoroil induced diarrhea but also it was producing an atropine sensitive spasmogenic effect in rabbit jejunum up to $5 \mathrm{mg} / \mathrm{mL}$, followed by a partial relaxation at $10 \mathrm{mg} / \mathrm{mL}$, when assessed on gut preparations. In the jejunum of mice and ileum of pig, both contractions and stimulations were recorded. Also in rabbit trachea, these effects were recorded. On activity-directed fractionation, inhibitions were found to be due to organic and stimulations due to aqueous fractions.

Thus, studies confirmed the presence of calcium antagonist activity, possibly underlying its medicinal outcome in hyperactive gut and respiratory disorders, and cholinergic activity, possibly underlying its digestive effect, provides logic for traditional therapeutic uses of D. bipinnata (Rahman et al., 2012).

The antioxidant activities of hydro-methanolic root extracts of Desmostachya bipinnata (L) depicted it to be most potent scavenger of hydrogen peroxide radicals (IC50 -127.07 $\pm 6.44 \mu \mathrm{g} / \mathrm{ml}$ ) against standard Ascorbic acid (IC50 $-122.60 \pm 2.17 \mu \mathrm{g} / \mathrm{ml}$ ). Antioxidant studies with hydro-alcoholic extractives have also been reported recently (Golla et al., 2014). In addition to above antioxidant studies, cytotoxic studies of the same extractives depicted significant toxicity against Hela (IC50 -109.8 $\mu \mathrm{g} / \mathrm{ml}$ ), HEp2 (IC50 $-166.8 \mu \mathrm{g} / \mathrm{ml}$ ) and NIH 3 T3 (IC50 -216 $\mu \mathrm{g} / \mathrm{ml}$ ) (Rahate et al., 2012).

Essential oil of aerial parts of Desmostachya bipinnata (L) was found to be considerably antimicrobial against Staphylococcus aureus, Staphylococcus epidermis, Escherichia coli and Pseudomonas aeruginosa (Kumar et al., 2010). Hydro-alcoholic extractives of Desmostachya bipinnata (L) showed certain toxicity of 17.4 and $42 \%$ death at 500 and 1000 ppm respectively.

This is to inferr that Desmostachya bipinnata (L) show variable levels of toxicity at high concentrations (Golla et al., 2011). Aqueous extractives of Desmostachya bipinnata (L) administered to urolithiasis induced test group rats at a dose of $400 \mathrm{mg} / \mathrm{kg}$ for 10 days depicted significant decrease in the quantity of calcium oxalate deposition in the kidneys. It also reversed all the biochemical changes induced by calcium oxalate urolithiasis (Kishore et al., 2014). Reports show that extracts of $D$. bipinnata possessed good antihistaminic activity, which was further confirmed with histamine induced lethality test (Singh et al., 2014). Extractives of Desmostachya bipinnata (L) have also been used in biogenic synthesis of silver nanoparticle which could be used for medicinal purposes (Garimella et al., 2014).

The hydro-alcoholic extractives of Desmostachya bipinnata (L) showed significant diuretic activity and also increased the urinary output at $500 \mathrm{mg} / \mathrm{kg}$ compared to furosemide $(\mathrm{P}<0.01)$. It also increased urinary electrolyte concentration $\left(\mathrm{Na}+, \mathrm{K}+\right.$, and $\left.\mathrm{Cl}^{-}\right)$. The results for laxative activity of 
Desmostachya bipinnata (L) showed minimal increase in feces output $(500 \mathrm{mg} / \mathrm{kg})$ compared to standard drug sennosides (Golla et al., 2014). Ethanolic extractives of Desmostachya bipinnata (L) has also been shown to inhibit various gram negative and gram positive bacteria and unicellular and filamentous fungi (Zain et al., 2014).

\section{The Cogon Grass, Imperata cylindrica $(\mathrm{L}$.}

Cogon grass, Imperata cylindrica (L) a species of grass in the family Poaceae. Red cultivars of the species grown as ornamental plants are known as Japanese bloodgrass. It is a perrenial, rhizomatous grass. It is somewhat variable in appearance. The species puts out extensive rhizomes. And the rhizome give rise to 3-10' long spreading stems and the leaf blade bunches that grow out of the stems. The leaf blades begin at ground level. The leaves typically range from 1-4 feet in length. Leafblade range from 1/2-3/4 inches in width, possess finely serrate sharp margins, a white, off-center mid-vein, and are hairy at the base. The margin of the leaf is finely serrate. The leaf margins contribute to the undesirable forage qualities of this grass. Young leaves of grass are light green while older leaves are orange-brown to brown in color. The ligules (membranous or hairy appendages at the junction between sheath and blade) are brown and papery. Cogongrass, Imperata cylindrica (L) is producing long, fluffy-white panicles (seed heads) (Langland and Burks 1998, MacDonald et al., 2006) (Fig. 2).

\section{Ethnic Prominence of Imperata cylindrica (L.)}

The cogon grass, Imperata cylindrica (L) was accidentally introduced to the United States in the first half of the 20th century. Originally cogon grass, Imperata cylindrica (L) arrived in the U.S. as packing material. In 1912, live cogon grass Imperata cylindrica (L) was reported near Grand Bay Alabama, apparently derived from orange crate packing material originating from Satsuma, Japan. A decade later, cogon grass Imperata cylindrica (L) from the Philippines was intentionally planted in Mississippi as an experimental forage plant. In the 1930s and 1940s, cogon grass Imperata cylindrica (L) was also planted in Florida for use as livestock forage and for erosion control (MacDonald et al., 2006).

Cogon grass Imperata cylindrica (L) was soon revealed to be a poor forage material, and it was a marginal sediment stabilizer as well. Instead, the Cogon grass Imperata cylindrica (L) was found to be a noxious pest species and further intentional planting of the species was prohibited. According to MacDonald et al., (2006), the reasons for the spread of this invasive Cogon grass Imperata cylindrica (L) include: Continued illegal planting; accidental dispersal through habitat disturbance; road construction; and forage transport. Recent spread of cogon grass Imperata cylindrica (L) into some formerly un-infested areas may be the result of accidental downstream transport of viable vegetative material that was uprooted or cut down in upstream infested habitats (Bennett, 2006).

The cogon grass, Imperata cylindrica $(\mathrm{L})$ is a perennial and rhizomatous grass. It is endemic to tropical and subtropical regions found throughout the world. It often surpasses areas concerned with human activities (Holm et al., 1977; Brook, 1989). This cogon grass, Imperata cylindrica (L) deserve significant characters, which include: extensive rhizome system; tolerance towards drought and saline soils; seed strategies based on wind dissemination; adaptation towards fire and high genetic plasticity (Hubbard et al., 1944; Holm et al., 1977; Brook, 1989; Dozier et al., 1998). These characters made cogon grass, Imperata cylindrica (L) persistent grass throughout the world. The cogon grass, Imperata cylindrica (L) is also termed as a 
successful invasive plant (Lucardi et al., 2014; Su et al., 2014). It is found in most of the continents. In Europe, it is found south of Mediterranean Sea and also in North Africa to the Middle East. Also, found in Iran, Afghanistan, Pakistan and as vast stretch of Grasslands in India (Garrity et al., 1997). Both halfa grass, Desmostachya bipinnata (L) and cogon grass, Imperata cylindrica (L) have been mentioned in Rig Veda and Atharvaveda. Charaka and Susrutha have also mentioned these grasses as galactagogue (promotes lactation in humans and other animals) and diuretic (increase the flow of urine by their action upon the kidney) (Madhihassan, 1987). Both halfa grass, Desmostachya bipinnata (L) and cogon grass, Imperata cylindrica (L) are ingredients in preparation of Tripanchmool.

The "Tripanchmool" is used in urinary calculi, retention of urine, diabetes, cardiac disorders, gout, common cough and cold, anemia (Ayurvedic Formulary of India, 2000). The young inflorescence, young shoots of cogon grass, Imperata cylindrica (L) are edible after cooking. The fibrous roots of cogon grass are rich in starch and sugar and good for eating. The cogon grass Imperata cylindrica (L) is also used medicinally in traditional practices to treat bacterial infections, helminthes. It is also used as an astringent (compound that tends to shrink or constrict body tissues). It is found effective in conditions like arthritis, dysentery, diarrhea, cancers, gonorrhea, diuresis etc. It is used as a febrifuge (medicine used to reduce fever), emollient (moisturizers, help skin to feel more comfortable and less itchy) and as a tonic (Datta S, 1978). Commercially, cogon grass Imperata cylindrica (L) is used for soil stabilization through stuffing, in paper industry (Dalziel, 1948) and weaving (Singh D, 2002). Commercially, this grass is used as fodder for cattle (Holm et al., 1977). It is also used as a material for thatched roofs in India and South East Asia (Potter et al., 2000).

\section{Bioactive compounds isolated from Imperata cylindrica (L.)}

The methyl ethers of triterpenes: Arundoin and Cylindrine are the first sets of compounds isolated from rhizomes of Imperata cylindrica, (L) (Nishimoto et al., 1965). Phytochemical study of the aerial parts of cogon grass, Imperata cylindrica (L.), growing in Egypt afforded four methoxylated flavonoids $1-4, \beta$ sitosterol-3-0- $\beta$-D-glucopyranosyl-6'-tetra

decanoate 5,3-hydroxy-4-methoxy benzaldehyde 6 , together with daucosterol, $\beta$ sitosterol and $\alpha$-amyrin 7-9. To the best of our knowledge, this is the first isolation of compounds 1-5 from the genus Imperata. There was a significant hepato-protective activity observed upon co-administration of the methanolic extracts of I. cylindrica with CC14. The structures were determined using spectroscopic data; 1D (1H and 13C), 2D (HSQC, and HMBC) NMR; MS; UV and IR (Mohamed, et al., 2009). The compound: Cylindrene, a sesquiterpenoid was isolated once again from rhizomes of cogon grass, Imperata cylindrica (L.) (Matsunaga et al., 1994). Matsunaga et al., (1994) isolated the two novel lignans, Graminone $\mathrm{A}$ and Graminone B, later from the same cogon grass, Imperata cylindrica (L.). The Graminone B at 10-4 M yielded a 50\% inhibition of the contractile response of the aorta isolated from rabbit to KCI $(30 \mathrm{mM})$ without affecting norepinephrine (10-7 M) induced contractions. Further studies in this cogon grass, Imperata cylindrica (L.) gave 4 chromones from methanolic extract of rhizomes, 5-hydroxy-2-(2-phenylethyl) chromone, 5-hydroxy-2-[2-(2-hydroxyphenyl) ethyl] chromone flidersiachromone, 5hydroxy-2-styrylchromone (Yoon et al., 2006). Compound 5-hydroxyl-2-(2phenylethyl) chromone and the compound 5hydroxy-2-[2-(2 hydroxyphenyl) ethyl] chromone exhibited significant neuroprotective response against glutamate- 
induced neurotoxicity at $10.0 \quad \mu \mathrm{M}$ concentration in primary cultures of cortical cells in rat. The compound, "impecyloside or 6-acetyl-1-[1,3-(4,40-dihydroxy-3,30dimethoxy-b-truxinyl)-b-Dfructofuranosyl]-aD-glucopyranoside", a novel lignin glycoside was later isolated from rhizomes of cogon grass, Imperata cylindrica (L.) (Lee et al., 2008). The hydr-oalcoholic extract of aerial parts of this cogon grass, Imperata cylindrica (L.) gave several compounds Tricin; Jaceidin; "Quercetagetin-3, 5,6,3'-tetramethyl ether"; "3,5-Di-O-methyl-kaempferol"; " $\beta$-Sitosterol3-0- $\beta$-D-glucopyranosy1-6-tetradecanoate"; "3-Hydroxy-4-methoxy benzal dehyde"; "daucosterol"; " $\beta$-sitosterol" and "a-amyrin" (Mohamed et al., 2009). For the first time from essential oil extract of aerial parts of cogon grass, Imperata cylindrica, (L.) a phytotoxic compound called "Tabanone" was isolated (Cerdeira et al., 2012). This "Tabanone" compound was found inhibiting the growth of frond area of duckweed; root growth of garden onion, and fresh weight gain of garden lettuce with $50 \%$ inhibition values of $0.094,3.6$, and $6.5 \mathrm{mM}$, respectively.

The target site of "tabanone" was found remains unknown, but its mode of action results in rapid loss of membrane integrity and subsequent decrease in the rate of photosynthetic electron flow. Chemical investigation of cogon grass, Imperata cylindrica (L.) led to the isolation of new compounds using various chromatographic techniques. They include the three phenylpropanoids: (i). 1-(3,4,5-trimethoxyphenyl)-1,2,3-propanetriol; $\quad$ (ii).1-O-pcoumaroylglycerol; (iii). 4-methoxy-5-methyl coumarin-7-O-beta-D-glucopyrano-side; the four organic acids: (i). 4-hydroxybenzene carboxylic acid; (ii). 3,4-dihydroxybenzoic acid; (iii). vanillic acid; (iv). 3,4dihydroxybutyric acid; one phenolic compound: salicin and triterpenes: fernenol; simiarenol; glutinone (Liu et al., 2010).
Advent of 2013 witness many new compounds being reported from this sacred grass with several phenolic compounds reported 4, 7dimethoxy-5-methylcoumarin; 7-hydroxy-4methoxy-5-methylcoumarin; $\quad 7-O-\beta-D$ glucopyranosyl-4-methoxy-5 methylcoumarin; 6-hydroxy-5-methoxyflavone; 5-methoxyflavone; 5, 7-dihydroxy-8-methoxyflavone; 4hydroxybenzaldehyde; 4-hydroxy-cinnamic acid; 4-hydroxy-3-methoxybenzoic acid; 3,4dimethoxyphenyl-O- $\alpha$-L-rhamnopyranosyl$(1 \rightarrow 6)-\beta$-D-glucopyranoside (Rong-hua et al., 2013). Also, two new chromones, 8-hydroxy2-(2- phenylethyl) chromone and 2-(2phenylethyl) chromone-8- $O-\beta$-Dglucopyranoside along with a novel flavone glycoside, 4'-methoxyflavone-6- $O-\beta$-Dglucopyranoside were reported (Xuan et al., 2013).

Recently few new compounds were isolated from cogon grass, Imperata cylindrica (L.), which include: impecylone; deacetylimpecyloside; seguinoside K 4methylether; impecylenolide; along with Impecyloside and seguinoside $\mathrm{K}$ (Liu et al., 2014).

\section{Bioactivity of extractives from Imperata cylindrica $(\mathrm{L})$}

Ten mircolitres of acetone maceratives of known strength of known herbal source of triterpenoids and acetone solution of known triterpenoid compound were topically applied separately to the fifth instar larvae of bivoltine silkworm, Bombyx mori (L) [Race: (CSR6 $\times$ CSR26) $\times$ CSR2 $\times$ CSR27)] at 48 hours after the fourth moult. The cocoons spinned by the larvae were used for analysis of shell ratio and silk filament for the denier scale. The shell ratio of the cocoons harvested from untreated and acetone treated groups was found measured 20.264 and 20.363 respectively. 
The denier scale of the silk filament obtained from the untreated control and acetone treated control groups was 2.704 and 2.705 respectively. Topical application of acetone maceratives of known herbal source of triterpenoid and acetone solution of known triterpenoid separately to the fifth instar larvae of bivoltine raced silkworm, Bombyx mori $(\mathrm{L})[(\mathrm{CSR} 6 \times \mathrm{CSR} 26) \times \mathrm{CSR} 2 \times$ CSR27)] was found resulted into the cocoons with 29.317 and 33.224 shell ratio respectively. The denier scale of silk filament reeled from the herbal and known triterpenoid groups was 2.839 and 3.217 respectively. The known herbal source of triterpenoids and known triterpenoid through acetone were found most significant with reference to the quality of the cocoons and silk filament in silkworm, Bombyx mori (L) [(CSR6 $\times$ CSR26) $\times$ CSR2 $\times$ CSR27)]. The herbal source of triterpenoids and the triterpenoids deserve applicability and exert a significant influence (Vitthalrao B. khyade, 2018). Many of the earlier reports demonstrated the medicinal properties of cogon grass, Imperata cylindrical (L.).

Cytotoxic studies on cogon grass, Imperata cylindrical (L.) extractives depicted IC50 values of $12.11 \mu \mathrm{g} / \mathrm{ml}$ (Mia PaCa2 cells), 8.4,
$7.18 \mu \mathrm{g} / \mathrm{ml}$ in leukemia cells (CCRFCEM, CEM/ADR5000). It also showed only 54.84\% inhibition of normal HUVEC cells at 80 $\mu \mathrm{g} / \mathrm{ml}$, with EC50 value of $47.73 \mu \mathrm{g} / \mathrm{ml}$ (Kuetea et al., 2010). Further studies in cytotoxicity were done with extractives of cogon grass, Imperata cylindrical (L.), which depicted cytotoxicity against cell lines with IC50 values of $3.28 \mathrm{mg} / \mathrm{mL}$ [against HCT116 (p53 -/-) cells] to $33.43 \mathrm{mg} / \mathrm{mL}$ (against HepG2 cells). The studies on influence of extractives of cogon grass, Imperata cylindrical (L.) on cell cycle distribution of CCRF-CEM cells revealed that, it is inducing the arrest between $\mathrm{Go} / \mathrm{G} 1$ and $\mathrm{S}$ phases. Further, CCRF-CEM cells treated with of extractives of cogon grass, Imperata cylindrical (L.), IC50 concentrations depicted progressive apoptosis, with percentages in sub-G0/G1 phase ranging from $40.5 \%$ (24h) to $80.4 \%$ (72h) (Kuete et al., 2013). There are the reports emerged that extractives from rhizomes of cogon grass, Imperata cylindrical (L.), inhibited Quorum-sensing metabolites of Chromobacterium violaceum CV026 with antibacterial zone of $12 \mathrm{~mm}$ and Quorumsensing inhibition zone of $20 \mathrm{~mm}$; however, it showed no inhibition on Pseudomonas aeruginosa PA01 (Koh et al., 2011).

Fig.1 The halfa grass, Desmostachya bipinnata (L)

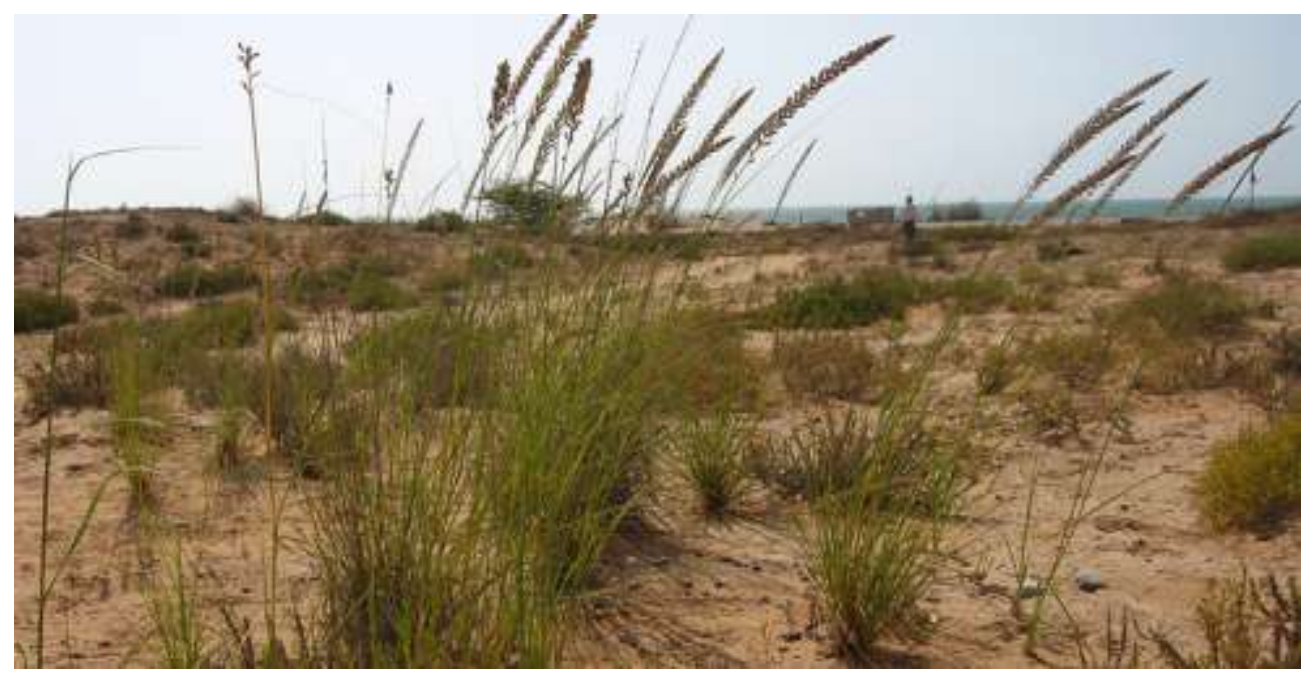


Fig.2 The cogon grass, Imperata cylindrica (L.)

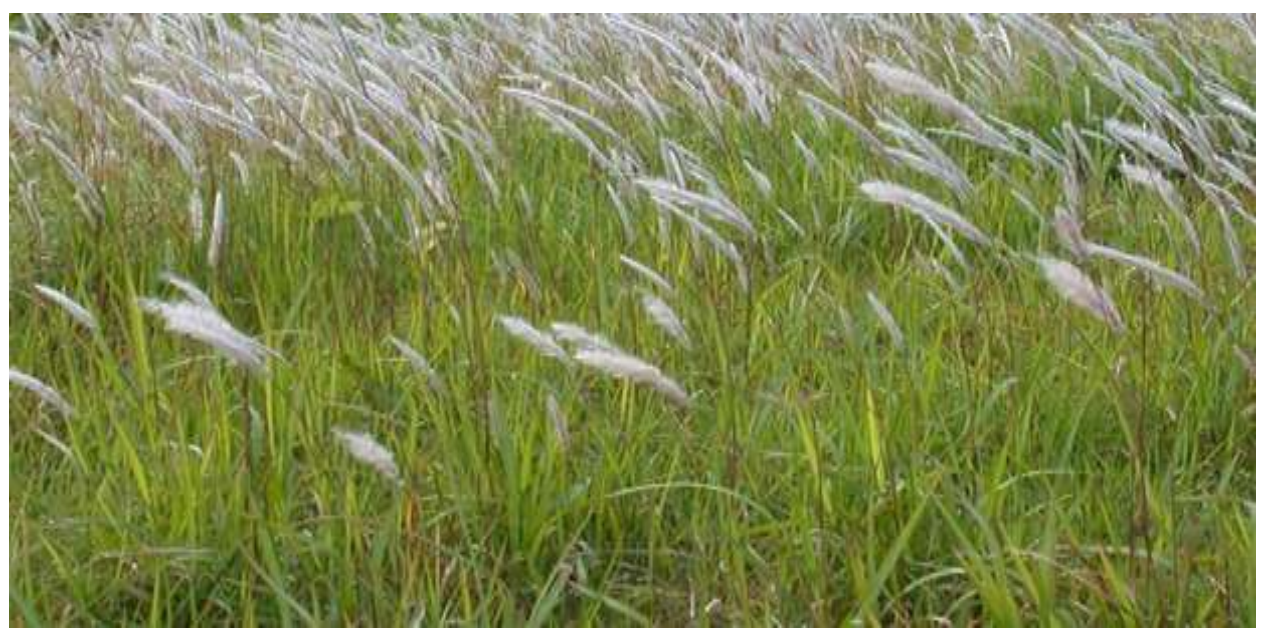

Antioxidant studies of hydroalcoholic root extract of this plant showed activity of 14.33 $\pm 0.045(10 \mu \mathrm{g} / \mathrm{ml})$ to $36.56 \pm 0.053(50$ $\mu \mathrm{g} / \mathrm{ml}$ ) by DPPH assay. Antioxidant activity was also confirmed with reduction by FRAP assay (Jayalakshmi et al., 2011). Hexane, ethyl acetate and methanol extracts of cogon grass, Imperata cylindrical (L.) was found working against Trypanosoma brucei rhodesiense STIB 900 (a parasite) with Mean IC50 of $12.56 \pm 0.09,42.49 \pm 0.99$ and 30.37 \pm 4.40 respectively (Abiodun, 2012). Aqueous exracts of cogon grass, Imperata cylindrica (L.) was also reported to have antiinflammatory activity by relieving the auricular edema in mice induced by dimethyl benzane, ameliorate the paw-swelling in rats (Yue et al., 2006).

In conclusions the present attempt tried it's best to review the literature on two grasses halfa grass, Desmostachya bipinnata (L) and cogon grass, Imperata cylindrical (L.), the novel medicinal grasses used in India in various traditional rituals. Both, halfa grass, Desmostachya bipinnata (L) and cogon grass, Imperata cylindrical (L.) belong to the same family. They are more or less used for similar kind of rituals. The medicinal value of halfa grass, Desmostachya bipinnata (L) and cogon grass, Imperata cylindrical (L.) is also documented in traditional Medicinal texts. Although, many compounds are discussed in the present attempt of review, it is evident that, only few compounds have been isolated so far from Desmostachya bipinnata (L.). Most of the chemical compounds are already known to be reported from other plants. Thus, it now essential to proceed further through more research efforts on sacred plant. The further efforts should be especially with more emphasis on isolation of new unreported compounds and efficient use of reported compounds to improve qualitative health. Some compounds of cogon grass, Imperata cylindrical (L.) should be (must be) utilized through acetone like solvent for topical application to fifth instar larvae of bivoltine silkworm, Bombyx mori (L) for qualitative silk cocoons. Taking into account all these aspects, it seems that through more research work in similar or allied domains of therapeutic realms, it is possible to find more bioactive molecules which could be utilized for expanding understanding of management of challenging diseases. It may open a new avenue in biotechnology.

\section{Acknowledgement}

28 January is birthday of Priti Madhukar Gaikwad (The first author of present attempt). 
Credit of whole reference work for present attempt goes to her kind self. The Science Association, Shardabai Pawar Mahila Mahavidyalaya, Shardanagar Baramati is wishing Priti Madhukar Gaikwad A Happy Birthday (28 January). The help received from International Science Community Association, Indore deserve appreciations and exert a grand salutary influence.

\section{References}

Abiodun OO, Gbotosho GO, Ajaiyeoba EO, Brun R,Oduola AM. 2012. Antitrypanosomal activity of some medicinal plants from Nigerian ethnomedicine. Parasitol Res. 110: 521526.

Ahmad R., Shaikh A.S. (January-June 2003). Common Weeds of Wheat and Their Control. Pakistan Journal of Water Resources 7 (1): 73-76

Amani SA, Nawal HM, Derek JM, Gamal AS. 2008. Anti-ulcerogenic activity of extract and some isolated flavonoids from Desmostachya bipinnata (L.) Stapf. Res Nat Prod 3: 76-82.

Anonymous. 2000. The Ayurvedic Formulary of India, Part (II), Ministry of Health and Family Welfare, Department of Indian System of Medicine and Homeopathy, Govt. of India, New Delhi, India.

Bennett, D. 2006. Cogongrass, deep-rooted sedge in Mississippi Delta. Delta Farm Press Oct 19, 2006 news story. https://www.sms.si.edu/irlspec/Imperata _cylindrica.htm

Bhalla PP. 2006. Hindu Rites, Rituals, Customs and Traditions: A to $\mathrm{Z}$ on the Hindu way of life. Pustak Mahal, India.

Bhat VS. 2005. Chemistry of natural products. Springer, UK.

Brook RM. 1989. Review of literature on Imperata cylindrica (L.) Raeuschel with particular reference to South East Asia.
Trop Pest Manage 35: 12-25.

Cerdeira AL, Cantrell CL, Dayan FE, Byrd JD, Duke SO. 2012. Tabanone, a new phytotoxic constituent of Cogongrass (Imperata cylindrica). Weed Science 60: $212-218$

Dalziel JM. 1948. The useful plants of west tropical Africa. Crown Agents, London, UK.

Datta S, Banerjee A. 1978. Useful weeds of West Bengal rice fields. Econ Bot 32: 297-310.

Dozier H, Gaffney JF, McDonald SK, Johnson ERRL, Shilling DG. 1998. Cogongrass in the United States: history, ecology, impacts, and management. Weed Technol 12: 737743.

Garimella S, Kudle KS, Prashanthi Y, Balla D, Preethi KS, Merugu R. 2014. Biogenic synthesis and characterization of silver nanoparticles using Desmostachya bipinnata. Nanosci Nanotechnol 4: 28-31.

Garrity DP. 1996/1997. Special Issue: Agroforestry innovations for Imperata grassland rehabilitation. Agroforestry Syst. 36: 1-284.

Golla UR, Gajam PK, Raj BSS. 2013. The effect of Desmostachya bipinnata (Linn.) extract on physiologically altered glycemic status in non-diabetic rats. J Med Sci 13: 221-225.

Golla UR, Gajam PK, Mohammad AR, Kumar AK, Raj BSS. 2011. Assessment of bioactivity of Desmostachya bipinnata (1.) Stapf using brine shrimp (Artemia salina) lethality assay. Pharmacologyonline 3: 982-990.

Golla UR, Raj BSS. 2014. Evaluation of antioxidant and DNA damage protection activity of the hydroalcoholic extract of Desmostachya bipinnata L. Stapf. The Scientific World J 1-8.

Golla UR, Gajam PK, Raj BSS. 2014. Evaluation of diuretic and laxative 
activity of hydroalcoholic extract of Desmostachya bipinnata (L.) Stapf in rats. J Int Med 12: 372-378.

Hegde MM, Lakshman K, Girija K, Ashok Kumar BS, Lakshmiprasanna V. 2010. Assessment of antidiarrhoeal activity of Desmostachya bipinnata L. (Poaceae) root extracts. Bol Latinoam Caribe Plant Med Aromat 9: 312-318.

Hifnawy MS, El-Hyatmy YY, Kenawy SA, Yossef AK, Awaad AS. 1999. Carbohydrate, lipid, protein and amino acid contents of Chenopodium murale, Cyperus alopecuroids, Desmostachya bipinnata and Tamaric nilotica as allergic plants. Bull Fac Cairo Univ 37: 99-106.

Holm LG, Pucknett DL, Pancho JB, Herberger JP. 1977. The World's Worst Weeds. Distribution and biology. Univ. Press of Hawaii, Honolulu, Hawaii.

Hubbard CE. 1944. Imperata cylindrica. Taxonomy, distribution, economic significance, and control. Imp. Agric. Bur. Joint Publ. No. 7, Imperial Bureau Pastures and Forage Crops, Aberystwyth, Wales. Great Britton.

Jayalakshmi S, Mishra A, Mishra A, Singlab RK, Ghosh AK. 2011. In-vitro Evaluation of antioxidant activity of five drugs of Trinpanchmool. Pharmacologyonline 2: 1153-1159.

Rahate KP, Rajasekaran A, Arulkumaran KSG. 2011. Potential of Desmostachya bipinnata Stapf. (Poaceae) root extracts in inhibition of cell proliferation of cervical cancer cell lines. Int $J$ Res Pharm Sci 3: 5-11.

Kirtikar KR, Basu BD. 1918. Indian medicinal plants. 4th vol. International book distributors book sellers and publishers, Dehradun, India.

Kishore Nr, Mangilal T, Anjaneyulu N, Abhinayani G, Sravya N. 2014. Investigation of antiurolithiatic activity of Brassica oleracea gongylodes and
Desmostachya bipinnata in experimentally induced urolithiasis in animal models. Int J Pharm Pharm Sci 6: 602-604.

Koh KH, Tham FY. 2011. Screening of traditional chinese medicinal plants for quorum-sensing inhibitors activity. $J$ Microbiol Immunol Infect 44: 144-148.

Kuete V, Sandjo LP, Wiench B, Efferth T. 2013. Cytotoxicity and modes of action of four Cameroonian dietary spices ethno-medically used to treat cancers: Echinops giganteus, Xylopia aethiopica, Imperata cylindrica and Piper capense. J Ethnopharmacol 149: 245-253.

Kuetea V, Krusche B, Youns B, Voukeng I, Fankam AG, Tankeo S, Lacmata S, Efferth T. 2011. Cytotoxicity of some Cameroonian spices and selected medicinal plant extract. $J$ Ethnopharmacol 134: 803-812.

Kumar AK, Sharvanee, Patel J, Choudhary RK. 2010. Chemical composition and antimicrobial activity of the essential oil of Desmostachya bipinnata (Linn.). Int J Phyt Med 2: 436-439,

Lee DY, Han KM, Song MC, Lee DG, Rho YD, Baek NI, 2008. A new lignan glycoside from the rhizomes of Imperata cylindrica. J Asian Nat Prod Res 10: 299-302.

Liu RH, Fu LN, Chen LY, Ren G, Chen SS, Chen Z. 2010. Chemical constituents and pharmacology study of Imperata cylindrica rhizomes. J Jiangxi Univ Tradit Chin Med 22: 80-83.

Liu X, Zhang BF, Yang L, Chou GX, Wang ZT. 2014. Four new compounds from Imperata cylindrica. J Nat Med 68: 295-301.

Lucardi RD, Wallace LE, Ervin GN. 2014. Evaluating hybridization as a potential facilitator of successful cogongrass (Imperata cylindrica) invasion in Florida, USA. Biol Invasions 16: 21472161. 
Mahdihassan S. 1987. Three important vedic grasses. Ind J Hist Sci 22: 286-291.

Matsunaga K, Ikeda M, Shibuya M, Ohizuni Y. 1994. Cylindol A, a novel biphenyl ether with 5- lipoxygenase inhibitory activity, and a related compound from Imperata cylindrica. J Nat Prod 57: 1290-1293.

Matsunaga K, Shibuya M, Ohizuni Y. Graminone B, a novel lignan with vasodilative activity from Imperata cylindrica. J Nat Prod 57: 1734-1736.

McDonald SK, Shilling DG, Okoli CAN, Bewick TA, Gordon D, Hall D, Smith R. 1996. Population dynamics of cogongrass. Proc. South. Weed Sci. Soc. 49: 156.

MacDonald G.E., Brecke B.J., Gaffney J.F., Langeland K.A., Ferrell J.A., and B.A. Sellers. 2006. Cogongrass (Imperata cylindrica (L.) Beauv.) biology, ecology and management in Florida. IFAS/UF document SS-AGR-52. https://www.sms.si.edu/irlspec/Imperata _cylindrica.htm

Mohamed GA, Lateff AA, Fouad MA, Ibrahim SRM, Elkhayat ES, Okino T. 2009. Chemical composition and hepato-protective activity of Imperata cylindrica Beauv. Phcog Mag 5: 28-36.

Nishimoto K, Ito M, Natori S. 1968. The structures of arundoin, cylindrin, and fernenol, Tetrahedron. 24: 725.

Packialakshmi N, Alwin. 2014. Analysis of phytochemical and high performance liquid chromatography in Desmostachya bipinnata. BMR Biotechnol. 1: 1-6.

Parvathy NG, Padma R, Renjith V, Rahate KP, Saranya TS. Phytochemical screening and anthelmintic activity of methanolic extract of Imperata cylindrica. Int J Pharm Pharmaceut Sci 4: 232-234.

Potter L, Lee J, Thorburn K. 2000. Reinventing Imperata: revaluing alang- alang grasslands in Indonesia. Dev Change 31: 1037-1053.

Prajapati ND, Purohit SS, Sharma AK, Kumar T. 2003. Handbooks of medicinal plants (A complete Source Book). Agrobios, India.

Rahman HMA, Bashir S, Gilani AH. 2012. Calcium channel blocking activity in Desmostachya bipinnata (L.) explains its use in gut and airways disorders. Phytother Res 27: 678 -684.

Ramadan MA, Safwat NA. 2009. Antihelicobacter activity of a flavonoid compound isolated from Desmostachya bipinnata. Aust J Basic Appl Sci 3: 2270-2277.

Rong-hua L, Sheng CS, Gang RG, Feng S, Lian HH. 2013. Phenolic Compounds from Roots of Imperata cylindrica var. major. Chin Herb Med 5: 240-243.

Samuelsson G. 1999. Drugs of Natural Origin: A Textbook of Pharmacognosy. Apotekarsocieteten, Sweden.

Shakila, R., Arul Antony S. and Gopakumar K. (2015). Phytochemical studies on Desmostachya bipinnata Root Stock. International Journal of Pharma and Bio Sciences 2015 Jan; 6(1): (P) 305310.

Shrestha S, Lyu HN, Park JH, Lee DY, Cho JG, Cui EJ, Chung IS, Baek NI. 2011. Sterols from the leafy culms of Desmostachya bipinnata. Chem Nat Compd 47: 852-853.

Shrestha S, Park JH, Lee DY, Cho JG, Cui EJ, Chung IS, Kwon BM, Cho MH, Jeong TS, Baek NI. 2011. A new Xanthene from Desmostachya bipinnata (L.) Stapf inhibits signal transducer and activator of transcription 3 (STAT3) and low-density lipoprotein-oxidation. $J$ Kor Soc Appl Biol Chem 54: 308-311.

Singh A, Saharan VA, Bhandari A. 2014. Pharmacognostic standardization with various plant parts of Desmostachya bipinnata. Pharm Biol 52: 298-307. 
Singh A, Saharan VA, Kumawat I, Veerma R, Bhandari A. 2014. Anti-histaminic Activity of Desmostachya bipinnata. J Biol Active Prod Nat 4: 7-15.

Singh D, Swarnkar CP, Khan FA. 2002. Anthelmintic resistance in gastrointestinal Nematodes in livestock. Ind J Vet Parasitol 16: 115-130.

Sivaranjan VV, Indira B. 1994. Ayurvedic drugs and their plant sources. Oxford \& IBH publishing co. Pvt. ltd, New Delhi, India.

Subramaniam S, Keerthiraja M, Sivasubramanian A. 2014. Synergistic antibacterial action of $\beta$ - sitosterol-Dglucopyranoside isolated from Desmostachya bipinnata leaves with antibiotics against common human pathogens. Rev Bras Farmacogn. 24: 44-50.

Su CX, Teng TT, Alkarkhi AFM, Low LW. 2014. Imperata cylindrical (Cogongrass) as an adsorbent for methylene blue dye removal: Process optimization. Water Air Soil Pollut. 225: 1941.

Vitthalrao B. Khyade (2018). Use of Herbal Terpenoid for topical application to fifth instars of silkworm, Bombyx mori (L). Abstract book: International Conference On Doubling the Farmers Income through Innovative Approaches, $9-11$ April, 2018 at Agricultural Development Trust's Krishi Vigyan Kendra, Baramati, Pune.

Vitthalrao B. Khyade and Sidney Altman (2018). Use of Herbal Terpenoid for topical application to fifth instars of silkworm, Bombyx mori (L). International Academic Journal of Science and Engineering Volume 5, Issue 3, July-September 2018

Vitthalrao B. Khyade and Manfred Eigen (2018). Key Role of Statistics for the Fortification of Concepts in Agricultural Studies. International Academic Journal of Innovative Research Vol. 5, No. 3, 2018, pp. 32-46.

Vitthalrao Bhimasha Khyade; Shubhangi Shankar Pawar and Jiwan Pandurang Sarwade (2018). Novel Sacrificial Medicinal Repositories: Halfa grass, Desmostachya bipinnata (L.) and Cogon grass, Imperata cylindrica (L.). World Scientific News WSN 100 (2018) 35-50 EISSN 2392-2192. www.worldscientificnews.com

Xuan L, Feng ZB, Li Y, Xin CG, Tao WZ. 2013. Two new chromones and a new flavones glycoside from Imperata cylindrica. Chin J Nat Med. 11: 77-80.

Yoon JS, Lee MK, Sung SH, Kim YC. 2006. Neuroprotective 2-(2-phenylethyl) chromones of Imperata cylindrica. $J$ Nat Prod 69: 290-291.

Yue X, Hou Z, Liu P, Wang S. 2006. Antiinflammatory effect of Imperata cylindrica. Chin J Clin Rehab 10: 8587.

Zain ME, Awaad AS, Othman MRA, AlDosary SK. 2014. Antibacterial, antifungal activity and phytochemical analysis of some desert plants against human pathogenic bacteria and fungi. Life Sci J 11: 343-349.

\section{How to cite this article:}

Priti Madhukar Gaikwad, Shubhangi Shankar Pawar and Vitthalrao Bhimasha Khyade. 2019. Halfa and Cogon: The Two Novel Grasses. Int.J.Curr.Microbiol.App.Sci. 8(01): 3014-3027. doi: https://doi.org/10.20546/ijcmas.2019.801.321 